\title{
Antioxidant System-Inducing Effects of Jeju Ground Water in C57BL/6 Mice against Gamma-ray Radiation
}

\author{
Areum Daseul Kim $\cdot$ Youngheun Jee $\cdot$ Ho Jin You $\cdot$ Jin Won Hyun
}

Received: 23 September 2011 / Accepted: 17 October 2011 / Published Online: 31 March 2012

(C) The Korean Society for Applied Biological Chemistry 2012

\begin{abstract}
Recently, we reported that Jeju ground water contains vanadium components and exerts antioxidant effects in vitro and in vivo via the scavenging of reactive oxygen species and enhancement of antioxidant enzyme activities. In the present study, the antioxidant actions of Jeju ground water were compared with those of tap water against gamma-ray radiation in mice. C57BL/6 mice were irradiated with gamma-ray at a dose rate of 2 Gy. The mice were then given tap water or Jeju ground water for 90 days. Jeju ground water compared with tap water enhanced the activities and levels of superoxide dismutase, catalase, and glutathione peroxidase in irradiated liver tissues. Jeju ground water also enhanced the levels of intracellular reduced glutathione, which is vital for normal liver function and repair. These results suggest that vanadium-containing Jeju ground water can safeguard against the harmful actions of gamma-ray radiation through the support of hepatic antioxidant processes.
\end{abstract}

Keywords antioxidant enzymes ' gamma-ray radiation · Jeju ground water $\cdot$ reactive oxygen species $\cdot$ vanadium

\section{Introduction}

Ionizing radiation provokes the decomposition reaction of water, producing a variety of reactive oxygen species (ROS) (Sadani and Nadkarni, 1997). The overproduction of ROS in various tissues

A. D. Kim · J. W. Hyun $(\bowtie)$

School of Medicine, Jeju National University, Jeju 690-756, Republic of Korea

E-mail: jinwonh@jejunu.ac.kr

Y. Jee

College of Veterinary Medicine, Jeju National University, Jeju 690-756, Republic of Korea

H. J. You

Department of Biomaterials, DNA Repair Center, Chosun University, Gwangju 501-759, Republic of Korea leads to significant alterations in cellular oxidant activity causing oxidative damage of lipids, proteins, and DNA (Navratil et al., 2008). The resultant cellular damage in turn leads to apoptosis, necrosis, cell dysfunction and/or mitotic cell death (Shimizu and Tsujimoto, 2000; Nair et al., 2001).

A search for chemical agents that can safeguard humans and other living organisms against ionizing radiation is an important pursuit in radiation biology (Nair et al., 2001). Recent efforts have focused on radio-protective chemicals and herbal extracts that have the capacity to modify immune and radiation responses (Goel et al., 2004; Arora et al., 2005; Maurya et al., 2006).

Organisms can adapt to increased ROS production by upregulating their antioxidant defenses, including the levels and activities of antioxidant enzymes (e.g., superoxide dismutase (SOD), catalase (CAT)) (Livingstone, 2003). Enzymes involved in glutathione metabolism (e.g., glutathione peroxidase (GPx) and glutathione reductase) are also up-regulated in response to elevated ROS levels (Galeotti et al., 1991; Portakal et al., 2000). In this regard, reduced glutathione (GSH) is a important antioxidant that provides crucial reducing equivalents for GPx (Winterbourn et al., 1993; Sheikh et al., 1998).

Vanadium is chemical element that exists in many oxidation states, from -1 to +5 . This enables the element to function as an electron transfer agent in a wide variety of reactions (Badmaev et al., 1999). Pharmacological applications of vanadium encompass the treatment of diabetes, hypertension, obesity, and inflammatory disorders, as well as cancer therapy (Hopfner et al., 1998; Bakhtiar and Ochiai, 1999; Thompson, 1999; Thompson and Orvig, 2001; Chakraborty et al., 2007). Recently, we reported that Jeju ground water containing the vanadium components, S1, S2, and S3 exhibited antioxidant effects via the scavenging of ROS such as superoxide anion and hydroxyl radical (Kim et al., 2010a). The S3 also enhanced the activities of SOD, CAT, GPx, and heme oxygenase-1 (HO-1) in vitro and in vivo (Kim et al., 2010b; 2011). In the present study, S1-, S2-, and S3-containing ground water preparations were compared with tap water for antioxidant system in gamma-ray irradiated $\mathrm{C} 57 \mathrm{BL} / 6$ mice. 


\section{Materials and Methods}

Jeju ground water preparation. Jeju ground water preparations containing the vanadium components, S1 $(8.0 \pm 0.9 \mu \mathrm{g} / \mathrm{L}), \mathrm{S} 2$ $(24.0 \pm 2.0 \mu \mathrm{g} / \mathrm{L})$, and $\mathrm{S} 3(26.0 \pm 2.0 \mu \mathrm{g} / \mathrm{L})$ were provided by the Jeju Special Self-Governing Province Development Corporation (Jeju, Korea).

Mice. C57BL/6 mice were purchased from Orientbio Inc. (Sungnam, Korea). The mice used for the experiments were of $6-$ 8 weeks of age and weighed 18-25 g. They were housed in conventional animal facilities at a constant temperature $\left(23 \pm 1^{\circ} \mathrm{C}\right)$ and provided with an NIH-07-approved diet and drinking water ad libitum, according to the Guidelines for the Care and Use of Laboratory Animals set forth by the Institutional Ethics Committee. The tap water was given throughout the course of the experiment (90 days) and corresponded to either Jeju ground water S1, S2, or S3.

Radiation with ${ }^{60} \mathrm{Co}$ gamma-ray. Each mouse was placed in a separate plastic container $(3 \times 3 \times 11 \mathrm{~cm})$ and given a single dose of gamma-ray radiation at a dose rate of $2.0 \mathrm{~Gy} / \mathrm{min}$. The sourcesurface distance was $150 \mathrm{~cm}$ from a ${ }^{60} \mathrm{Co}$ irradiator (Applied Radiological Science Institute, Jeju National University, Jeju, Korea).

SOD activity. SOD activity was measured in mouse liver tissue using a colorimetric assay kit (Abcam, Cambridge, MA) according to the manufacturer's protocol. The kit utilized the cell proliferation reagent WST-1, a tetrazolium salt, produces a watersoluble formazan dye that can be detected at $450 \mathrm{~nm}$ upon the reduction of WST-1 by superoxide anion. WST-1 reduction is inhibited by SOD, which catalyzes the dismutation of the superoxide anion to produce $\mathrm{H}_{2} \mathrm{O}_{2}$ and $\mathrm{O}_{2}$. Therefore, SOD activity was calculated on the basis of the percent inhibition of WST-1 reduction, which in turn reflected the percent inhibition of the superoxide anion.

CAT activity. CAT activity was measured in mouse liver tissue using a CAT assay kit (Abcam) according to the manufacturer's protocol. CAT reacts with $\mathrm{H}_{2} \mathrm{O}_{2}$ to produce $\mathrm{H}_{2} \mathrm{O}$ and $\mathrm{O}_{2}$. Unconverted $\mathrm{H}_{2} \mathrm{O}_{2}$ reacts with the OxiRed probe provided in the kit to produce a product that can be detected at $570 \mathrm{~nm}$. CAT activity was expressed in $\mathrm{mU} / \mathrm{mL}$.

GPx activity. GPx activity was determined in mouse liver tissue using the GPx assay kit (Oxford Biomedical Research, Rochester Hills, MI) according to the manufacturer's protocol. The GPx enzyme reaction was indirectly assessed following the addition of tert-butyl hydroperoxide to the liver lysate. GPx catalyzes the reduction of tert-butyl hydroperoxide by GSH. Oxidized glutathione (GS-SG) is then reverted to GSH by a reaction between glutathione reductase and NADPH. The resultant oxidation of NADPH to $\mathrm{NADP}^{+}$yields a decrease in absorbance at $340 \mathrm{~nm}$. The rate at which absorbance of $340 \mathrm{~nm}$ decreases is therefore directly proportional to the activity of GPx. GPx activity was expressed in $\mathrm{mU} / \mathrm{mL}$.

Western blot analysis. Liver tissues were lysed in $0.5 \mathrm{~mL}$ of a lysis buffer consisting of $120 \mathrm{mM} \mathrm{NaCl}, 40 \mathrm{mM}$ Tris (pH 8), and
$0.1 \%$ NP-40. Aliquots of the lysates ( $40 \mu \mathrm{g}$ protein) were boiled for $5 \mathrm{~min}$ and electrophoresed in a 10\% SDS poly-acrylamide gel. The gels were transferred onto nitrocellulose membranes (BioRad, Hercules, CA). Nitrocellulose membranes were subsequently incubated with primary antibodies against SOD, CAT, or GPx. The membranes were further incubated with secondary antiimmunoglobulin-G horseradish peroxidase conjugate (Pierce, Rockford, IL), followed by exposure to X-ray film. The protein bands were detected using an enhanced chemiluminescence Western blotting detection kit (Amersham, Little Chalfont, Buckinghamshire, UK) according to the manufacturer's instructions.

Intracellular GSH measurement. The intracellular GSH content was measured using the GSH-400 colorimetric assay kit (OXIS International, Portland, OR), as follows. Liver tissues were homogenized in a metaphosphoric acid working solution. After centrifugation, $50 \mathrm{~mL}$ of a chromogenic reagent solution in $\mathrm{HCl}$ was added to $900 \mathrm{~mL}$ of supernatant, followed by gentle vortex mixing. Following the addition of $50 \mathrm{~mL}$ of $30 \% \mathrm{NaOH}$, the mixtures were incubated at $25 \pm 3^{\circ} \mathrm{C}$ for $10 \mathrm{~min}$. After centrifugation, the absorbance of the clear supernatant was measured at $400 \mathrm{~nm}$. GSH level was measured in mM.

Statistical analysis. All values are represented as the mean \pm the standard error (SE). Data were analyzed with analysis of variance (ANOVA) using the Tukey test. A $p<0.05$ value was considered statistically significant.

\section{Results and Discussion}

Radiation exposure attenuates the expression and activity of endogenous antioxidant enzymes, which are considered to function as a first line of defense to maintain cellular redox balance and normal biochemical processes. Thus, supplementation of antioxidants to improve the efficacy of radiotherapy is currently proposed as a strategy to counteract radiation-induced damage (Barker et al., 2005). Antioxidants are capable of scavenging free radicals (e.g., ROS) that are generated from the radiolysis of water, thereby providing protection to cells and tissues against harmful rays (Mansour et al., 2008). Indeed, most of the toxic effects of ionizing radiation to normal cells and tissues can be attributed to the generation of ROS, given that ROS trigger the formation of several reactive intermediates. Healthy cells are equipped with a comprehensive and integrated endogenous antioxidant enzymatic system that includes SOD, CAT, GPx, and the GSH substrate, GSH. In addition, cells are equipped with nonenzymatic antioxidant systems (Karbownik and Reiter, 2000). However, as noted above, these antioxidant system must be augmented following exposure to ionizing radiation in order to overcome radiation-induced oxidative stress.

Recently, we reported that vanadium-containing Jeju ground water exerted antioxidant effects via the enhancement of antioxidant enzyme activities in vivo (Barker et al., 2005). Furthermore, Jeju ground water sustained immune activities that were suppressed by 


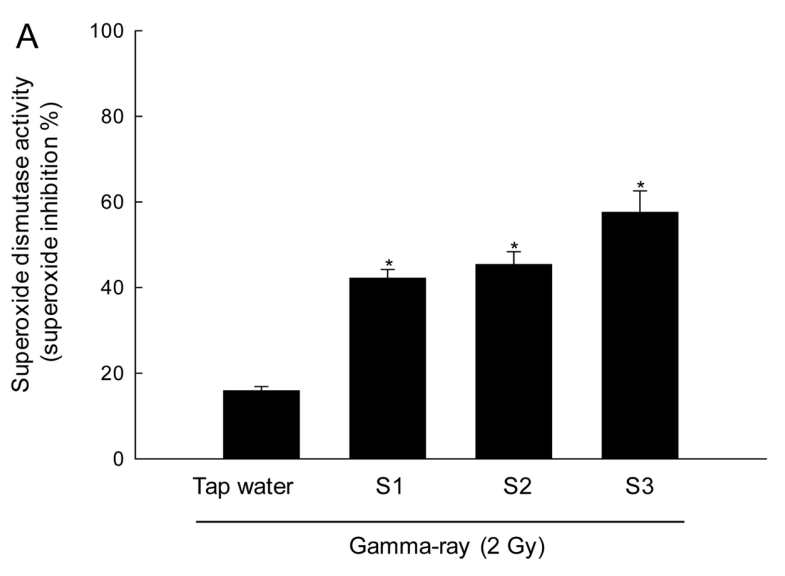

B

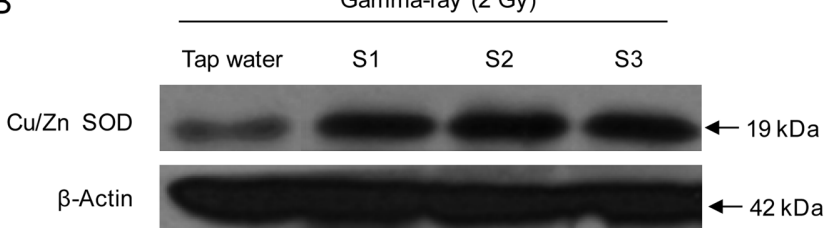

Fig. 1 Effect of S1, S2 and S3 on SOD activity in gamma-ray irradiated mice. (A) SOD activity was measured using a SOD activity colorimetric assay kit. All values are represented as the mean $\pm \mathrm{SE}$. * indicates significantly different from tap water $(p<0.05)$. (B) Liver tissue lysates were electrophoresed on an SDS polyacrylamide gel. The gel was transferred to a nitrocellulose membrane, and the $\mathrm{Cu} / \mathrm{Zn}$ SOD protein was detected using $\mathrm{Cu} / \mathrm{Zn}$ SOD specific antibody.

gamma ray radiation (Ha et al., 2011). The current study was designed to evaluate the antioxidant properties of vanadiumcontaining Jeju ground water against gamma-ray-induced damage in C57BL/6 mice. To do so, mice were provided with drinking water that corresponded to either tap water or Jeju ground water containing the vanadium components $\mathrm{S} 1, \mathrm{~S} 2$, or $\mathrm{S} 3$. The activity and expression of various antioxidant enzymes in mouse liver tissue, including SOD, CAT, and GPx were then evaluated.

SOD dismutates the superoxide radical into hydrogen peroxide and molecular oxygen (Singh et al., 2008). As shown in Fig. 1A, S1, S2, and S3 preparations displayed 42,45 , and $57 \%$ inhibition of the superoxide anion, respectively, compared with $15 \%$ inhibition by tap water. These results are consistent with the expression level of the $\mathrm{Cu} / \mathrm{Zn}$ SOD protein following the different treatments; notably, $\mathrm{Cu} / \mathrm{Zn}$ SOD expression was elevated following the administration of ground water S1, S2, and S3 as compared with tap water (Fig. 1B).

CAT is located at the peroxisome and converts hydrogen peroxide into molecular oxygen and water. Thus, CAT plays important roles in cellular protection from oxidative stressinduced cellular damages (Forstrom et al., 1978; Ceballos-Picot et al., 1992; Kawakami et al., 2006). S1, S2, or S3 all increased the activity of CAT. CAT exhibited activities of 163, 167, and 168 $\mathrm{mU} / \mathrm{mL}$ following the administration of ground water S1, S2, and S3, respectively (Fig. 2A). The corresponding value following the administration of tap water was $121 \mathrm{mU} / \mathrm{mL}$ (Fig. 2A). Moreover,
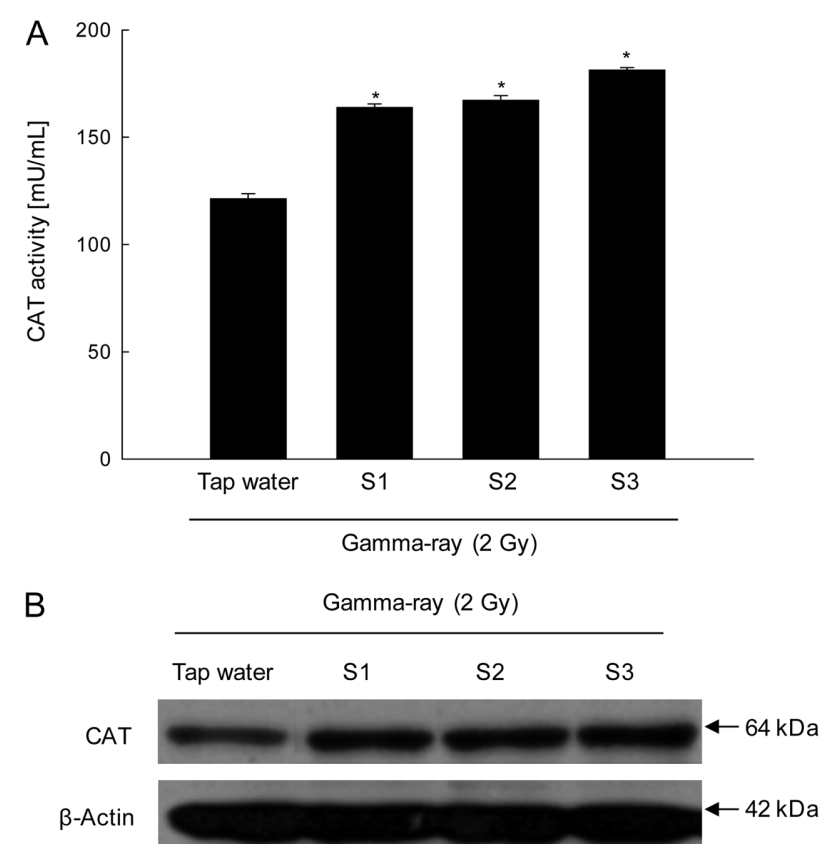

Fig. 2 Effect of S1, S2 and S3 on CAT activities in gamma-ray irradiated mice. (A) CAT activity was measured using a CAT assay kit. All values are represented as the mean $\pm \mathrm{SE}$. * indicates significantly different from tap water $(p<0.05)$. (B) Liver tissue lysates were electrophoresed on an SDS polyacrylamide gel. The gel was transferred to a nitrocellulose membrane, and the CAT protein was detected using CAT specific antibody.

$\mathrm{S} 1, \mathrm{~S} 2$, or S3 all increased CAT protein expression compared with tap water (Fig. 2B).

GPx uses GSH to catalyzes the reduction of hydroperoxides, including hydrogen peroxide, and functions to protect cells from oxidative damage (Guemouri et al., 1991). S1, S2, and S3 also augmented the activity of GPx. GPx showed activities of 67, 73, and $85 \mathrm{mU} / \mathrm{mL}$ following the administration of $\mathrm{S} 1, \mathrm{~S} 2$, and $\mathrm{S} 3$, respectively, and $38 \mathrm{mU} / \mathrm{mL}$ following the administration of tap water (Fig. 3A). Western blot results confirmed that S1, S2, and S3 enhanced the protein expression of GPx compared with tap water (Fig. 3B).

As described above, GSH is an antioxidant protein that helps to slow the molecular oxidation. GSH therefore provides protection from harmful effects of free radicals. Chemically, GSH contains three basic amino acids; cysteine, glycine, and glutamic acid. GSH exists in two forms, namely the reduced-form (GSH, monomer) and the oxidized-form (GS-SG, dimer). The former represents active glutathione, whereas the latter is acted upon by reductase, converting it into active GSH (Ulusu et al., 2003). Increased cellular GSH levels are suggested to result from the activation of protective tissue responses that regulate physiological mechanisms within cells through redox balancing reactions (Pathak et al., 2007). As shown in Fig. 4, S1, S2, and S3 increased intracellular GSH content as determined by a colorimetric assay. The GSH content was 97, 69, and $105 \mu \mathrm{M}$ following the administration of S1, S2, and S3, respectively, versus $73 \mu \mathrm{M}$ 


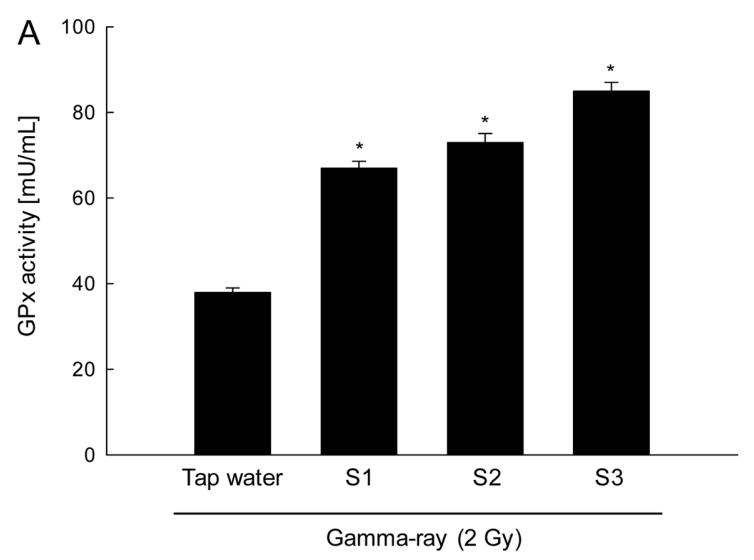

B

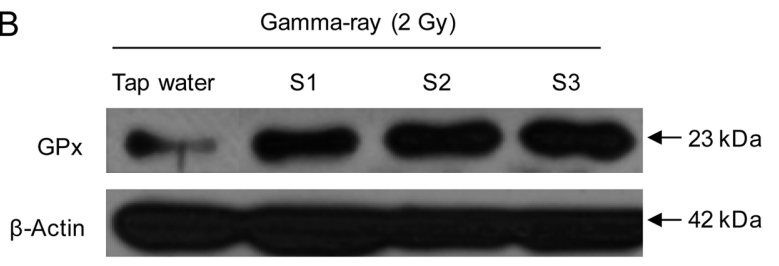

Fig. 3 Effect of S1, S2 and S3 on GPx activities in gamma-ray irradiated mice. (A) GPx activity was measured using GPx assay kit. All values are represented as the mean $\pm \mathrm{SE}$. * indicates significantly different from tap water $(p<0.05)$. (B) Liver tissue lysates were electrophoresed on an SDS polyacrylamide gel. The gel was transferred to a nitrocellulose membrane, and the GPx protein was detected using GPx specific antibody.

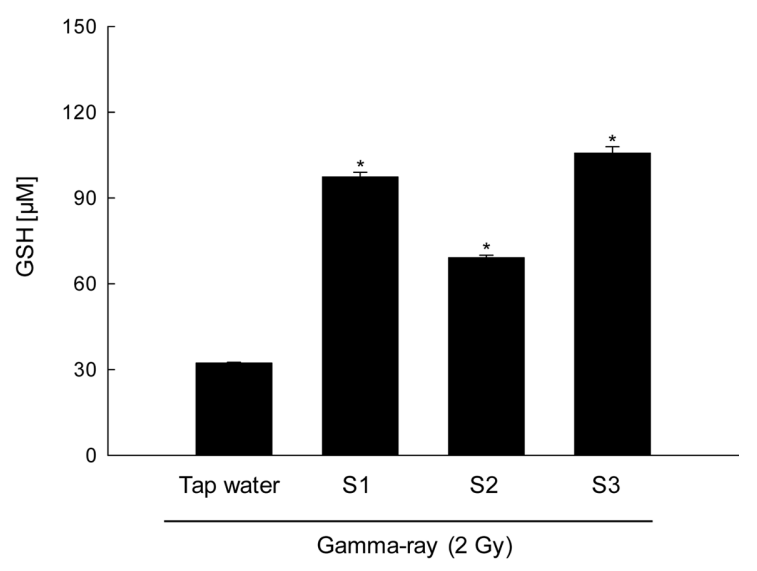

Fig. 4 Effect of S1, S2 and S3 on GSH level in gamma-ray irradiated mice. The intracellular GSH content was measured in liver tissue lysates using a colorimetric assay kit. All values are represented as the mean $\pm \mathrm{SE}$. * indicates significantly different from tap water $(p<0.05)$.

following the administration of tap water.

In conclusion, the results of this study indicate that vanadiumcontaining Jeju ground water exhibits antioxidant effects against gamma-ray irradiation in C57BL/6 mice by enhancing the expression and activity of hepatic antioxidant enzymes, and by enhancing the content of GSH.
Acknowledgment. This research was financially supported by the Ministry of Knowledge Economy (MKE), Korea Institute for Advancement of Technology (KIAT) and Jeju Leading Industry Office through the Leading Industry Development for Economic Region.

\section{References}

Arora R, Gupta D, and Chawla R (2005) Radioprotection by plantproducts: present status and future prospects. Phytother Res 19, 1-22.

Badmaev V, Prakash S, and Majeed M (1999) Vanadium: A review of its potential role in the fight against diabetes. J Altern Complement Med $\mathbf{5}$, 273-291.

Bakhtiar R and Ochiai EI (1999) Pharmacological applications of inorganic complexes. Gen Pharmacol 32, 525-540.

Barker S, Weinfeld M, Zheng J, Li L, and Murray D (2005) Identification of mammalian proteins cross-linked to DNA by ionizing radiation. $J$ Biol Chem 280, 33826-33838.

Ceballos-Picot I, Trivier J, and Nicole A (1992) Age-correlated modifications of copper-zinc superoxide dismutase and glutathione-related enzyme activities in human erythrocytes. Clin Chem 38, 66-70.

Chakraborty T, Chatterjee A, Rana A, Dhachinamoorthi D, Kumar PA, and Chatterjee M (2007) Carcinogen-induced early molecular events and its implication in the initiation of chemical hepatocarcinogenesis in rats: Chemopreventive role of vanadium on this process. Biochim Biophys Acta 1772, 48-59.

Forstrom JW, Zakowski JJ, and Tappel AL (1978) Identification of the catalytic site of rat liver glutathione peroxidase as selenocysteine. Biochemistry 17, 2639-2644.

Galeotti T, Masotti L, Borrello S, and Casali E (1991) Oxyradical metabolism and control of tumor growth. Xenobiotica 21, 1041-1051.

Goel HC, Prasad J, and Singh S (2004) Radioprotective potential of an herbal extract of Tinospora cordifolia. $J$ Radiat Res 45, 61-68.

Guemouri L, Artur Y, Herbeth B, Jeandel C, Cuny G, and Siest G (1991) Biological variability of superoxide dismutase, glutathione peroxidase, and catalase in blood. Clin Chem 37, 1932-1937.

Ha De, Kim MJ, Joo H, Cho J, Bing SJ, Lim YK, Hyun JW, and Jee Y (2011) Immuneactivation of Jeju water containing vanadium on peripheral immunocytes of low dose gamma rays-irradiated mice. Korean $J$ Vet Publ Hlth 35, 49-59.

Hopfner RL, McNeill JR, and Gopalakrishnan V (1998) Vanadate treatment normalizes exaggerated vascular smooth muscle responses in the obese Zucker rat. Eur J Pharmacol 357, 61-65.

Karbownik M and Reiter RJ (2000) Antioxidative effects of melatonin in protection against cellular damage caused by ionizing radiation. Proc Soc Exp Biol Med 225, 9-22.

Kawakami T, Takahashi T, Shimizu H, Nakahira K, Takeuchi M, Katayama H, Yokoyama M, Morita K, Akagi R, and Sassa S (2006) Highly liverspecific heme oxygenase-1 induction by interleukin-11 prevents carbon tetrachloride-induced hepatotoxicity. Int J Mol Med 18, 537-546.

Kim AD, Kang KA, Zhang R, Lim CM, Jee Y, Lee NH, You HJ, Ko KS, and Hyun JW (2010a) Reactive oxygen species scavenging effects of jeju waters containing vanadium components. Cancer Prev Res 15, 111-117.

Kim AD, Kang KA, Zhang R, Piao MJ, Kim S, Jee Y, Lee NH, You HJ, Ko $\mathrm{KS}$, and Hyun JW (2010b) Effect of jeju water containing vanadium on antioxidant enzymes in vitro. Cancer Prev Res 15, 262-267.

Kim AD, Kang KA, Zhang R, Piao MJ, Kim S, Jee Y, Lee NH, You HJ, Ko KS, and Hyun JW (2011) Antioxidant enzyme-enhancing effects of Jeju water containing vanadium in vivo. Cancer Prev Res 16, 58-64.

Livingstone DR (2003) Oxidative stress in aquatic organisms in relation to pollution and aquaculture. Revue Med Vet 154, 427-430.

Mansour HH, Hafez HF, Fahmy NM, and Hanafi N (2008) Protective effect of $\mathrm{N}$-acetylcysteine against radiation induced DNA damage and hepatic toxicity in rats. Biochem Pharmacol 75, 773-780.

Maurya DK, Devasagayam TP, and Nair CK (2006) Some novel approaches for radioprotection and the beneficial effect of natural products. $J$ Exp 
Biol 44, 93-114.

Nair CK, Parida DK, and Nomura T (2001) Radioprotectors in radiotherapy. $J$ Radiat Res 42, 21-37.

Navratil L, Racek J, Havrankova R, Beranek L, Skalicka ZF, Siffnerova H, and Kantorova E (2008) Changes in selected parameters of the antioxidant system in radiation damage to the organism. $J$ Appl Biomed 6, 195-201.

Pathak CM, Avti PK, Kumar S, Khanduja KL, and Sharma SC (2007) Whole body exposure to low-dose gamma radiation promotes kidney antioxidant status in Balb/c mice. J Radiat Res 48, 113-120.

Portakal O, Ozkaya, O, Erden Inal M, Bozan B, Kosan M, and Sayek I (2000) Coenzyme Q10 concentrations and antioxidant status in tissues of breast cancer patients. Clin Biochem 33, 279-284.

Sadani GR and Nadkarni GD (1997) Changes in lipid peroxide levels and the activity of reactive oxygen scavenging systems in thyroid tissue after exposure to radioactive iodine in rats. Thyroid 7, 937-941.

Sheikh FG, Pahan K, Khan M, Barbosa E, and Singh I (1998) Abnormality in catalase import into peroxisomes leads to severe neurological disorder. Proc Natl Acad Sci 95, 2961-2966.
Shimizu S and Tsujimoto Y (2000) Proapoptotic BH3 only Bcl-2 family members induce cytochrome-C release, but not mitiochondrial membrane potential loss and do not directly modulate voltage dependent anion channel activity. Proc Natl Acad Sci 97, 577-582.

Singh N, Kamath V, Narasimhamurthy K, and Rajini PS (2008) Protective effect of potato peel extract against carbontetrachloride-induced liver injury in rats. Environ Toxicol Pharmacol 26, 241-246.

Thompson KH (1999) Vanadium and diabetes. Biofactors 10, 43-51.

Thompson KH and Orvig C (2001) Coordination chemistry of vanadium in metallopharmaceutical candidate compounds. Coord Chem Rev 219221, 1033-1053.

Ulusu NN, Sahilli M, Avci A, Canbolat O, Ozansoy G, Ari N, Bali M, Stefek M, Stolc S, Gajdosik A, and Karasu C (2003) Pentose phosphate pathway, glutathione-dependent enzymes and antioxidant defense during oxidative stress in diabetic rodent brain and peripheral organs: Effects of stobadine and vitamin E. Neurochem Res 28, 815-823.

Winterbourn CC (1993) Superoxide as an intracellular radical sink. Free Radic Biol Med 14, 85-90. 